\title{
Simulation of Type 1Fuzzy Logic MPPT Controller for PV System
}

\author{
Ashwini Shetty ${ }^{1}$, Dinesh Shetty ${ }^{2}$ \\ PG Scholar, Electrical and Electronics Engg., NMAM Institute of technology, Nitte, India ${ }^{1}$ \\ Assistant Professor, Electrical and Electronics Engg., NMAM Institute of technology, Nitte, India ${ }^{2}$
}

\begin{abstract}
Solar supported power system is widely used to meet the reliable power supply to the load. Efficient power can be extracted from solar photovoltaic array using different Maximum power point tracking techniques. This paper presents the implementation of Type 1 Fuzzy Logic MPPT controller. DC-DC converter is placed between PV panel and load to get the required voltage at a load side. Linguistic rule based Fuzzy algorithm is applied to control boost converter for maximum power point tracking, To modulate the DC-DC converter linguistic variables are implemented in the fuzzy logic controller. Type 1 controller is capable of tracking maximum power under varying weather conditions, great execution and good accuracy compared to conventional method. The proposed method is validated by simulation using MATLAB/SIMULINK.
\end{abstract}

Keywords: Photovoltaic, Fuzzy Logic controller, DC-DC converter, linguistic variable.

\section{INTRODUCTION}

Power sector is the main concern in regularly increasing power demand. It can be accomplished by the use of conventional or non-conventional energy. Photovoltaic is one of the widely available energy but due to environmental issue the power decreases. Maximum power point tracking is utilized to maintain the power. Many approaches have been developed such as Perturbation and observation (P\&O),Constant voltage tracking $(\mathrm{CV})$ and Incremental conductance (INC).

However the $(\mathrm{P} \& \mathrm{O})$ algorithm has limitations that reduceits MPPT efficiency. One such limitation is that as the amount of sunlight decreases the Power voltage curve flatterns out. This method becomes unstable with rapid change in atmospheric condition .

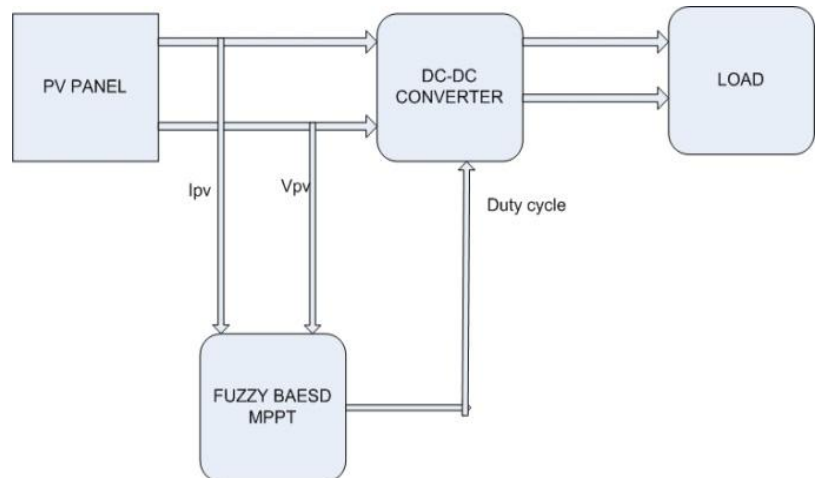

Fig. 1. Block diagram of proposed system

A. PV System

Number of cells are connected in series and parallelin the PV module to obtain desired output voltage andcurrent.Theequivalent circuit of a PV cell is represented in a one-diode model as shown in Fig. 2.

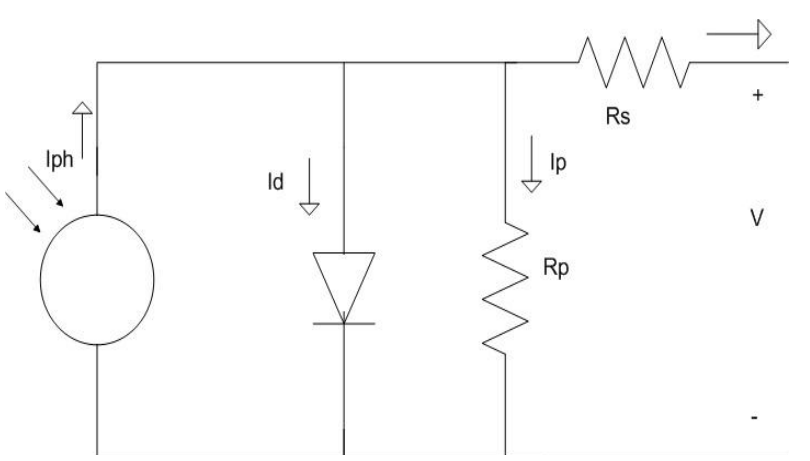

Fig.2. Equivalent circuit of PV cell

The Type 1 Fuzzy controller generates the PWM signal to switch of the DC-DC converter. 
The mathematical expression for equivalent circuit is technique.As this method becomes unstable with rapid shown below

$$
\begin{gathered}
I=I_{p h}-I_{d}-I_{p} \\
I=I_{p h}-I_{0}\left[\exp \left(\frac{V+I R_{s}}{A N_{s} V_{T}}\right)-1\right]-\left(\frac{V+I R_{s}}{R_{p}}\right)
\end{gathered}
$$

Where $V_{T}=\frac{K T_{c}}{q}$ change in atmospheric conditions such as irradiance and temperatureit oscillates around the maximum power point. Also it reduces the maximum power point tracking efficiency.

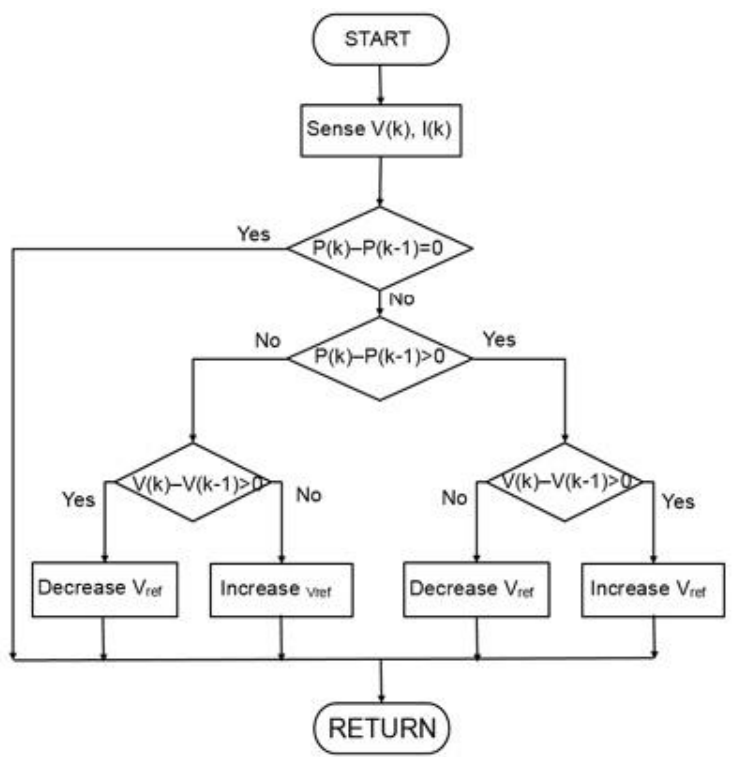

Fig.4. Perturb\& Observe Algorithm

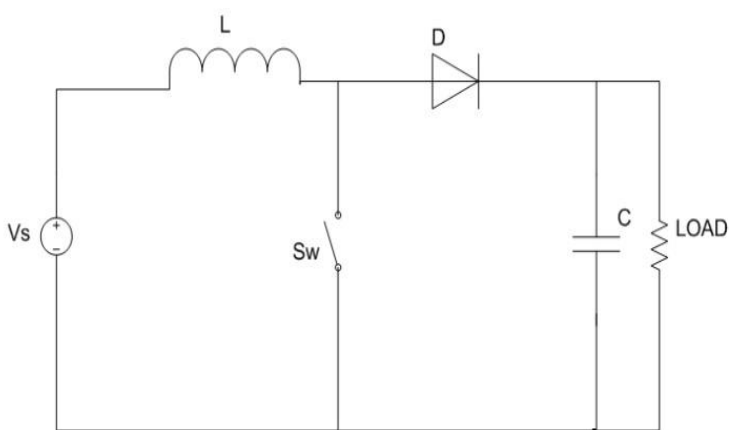

Fig.3. Circuit diagram of boost converter

III. MAXIMUM POWER POINT TRACKING MPPT controller is used to maintain the maximum power produced by PV array. Maximum power point tracking consists of different techniques .Few of most popular methods are

- Perturb and observe (P\&O),

- Incremental conductance method,

- Fractional short circuit current,

- Fractional open circuit voltage,

- Fuzzy logic,

- Neural networks.

C. Perturb and Observe method

$\mathrm{P} \& \mathrm{O}$ is an iterativemethod, it senses operating voltage continuously and compares the present output power with that of the previous power and resulting change in power is observed. The Fig. 4 shows the flowchart for $\mathrm{P} \& \mathrm{O}$
D. Type 1 Fuzzy Logic MPPT Controller

Fuzzy logic controller is widely used method which gives good accuracy compared to other Algorithm. Type 1 FLC check the PV power at each sample and calculates the change in power with respect to voltage $(d p / d v)$.If the $(d p / d v)$ is greater than zero, the FLC changes the dutycycle of the PWM to increase the voltage until themaximum power is achieved. If the $(d p / d v)$ is less than zero,the FLC changes the duty cycle of the PWM to decreasethe voltage until the power reached its maximum. The block diagram of fuzzy controller is shown in Fig.5. It consists of three modules, they are fuzzification inference, defuzzification.

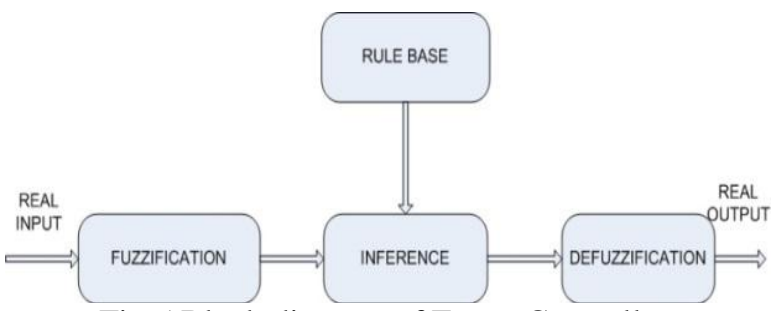

Fig.5 Block diagram of Fuzzy Controller

(4)

$$
\begin{aligned}
E= & \frac{P(k)-P(k-1)}{V(k)-V(k-1)} \\
& C E=E(k)-E(k-1)
\end{aligned}
$$


whereP $(\mathrm{k})$ is power of PV generator,error and change in In defuzzification, the fuzzy value is converted back to error are two input variables with triangular membership realvalue. In the proposed scheme centroid method is function.

\section{E. Fuzzification}

In fuzzification, the real value is converted into fuzzy value using some membership function.

\section{$F$. Inference}

The fuzzy inferenceis based on the Mamdanis's method which isassociated with the max-min method. There are five membership function named as NB(negative big), NS (negative small), ZE(zero), PS(positive small), $\mathrm{PB}$ (positive big). The rule table is designed andshown in Table 1.

\section{G. Defuzzification}

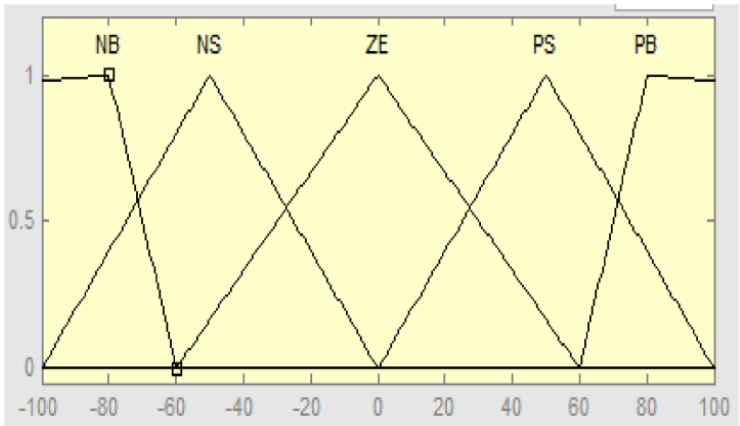

Fig.6.Membership function for input variable Error(E)

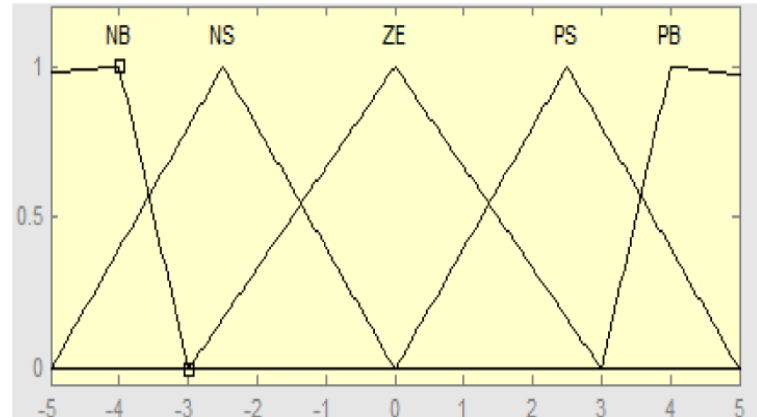

Fig.7.Membership function for input variable Change in error(CE)

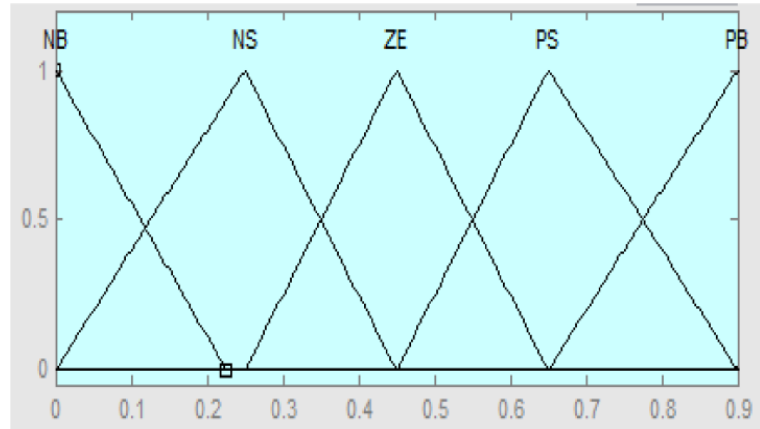

Fig.8.Membership function for output variable dutycycle (D) applied to return a proper value for the variation of duty cycle $(\Delta D)$. The output of fuzzy controller is given to switch of boost converter.

TABLE I FUZZY RULE TABLE

\begin{tabular}{|l|l|l|l|l|l|}
\hline $\begin{array}{l}\text { CE } \\
\text { E }\end{array}$ & NB & NS & ZE & PS & PB \\
\hline NB & ZE & ZE & PS & NS & NB \\
\hline NS & ZE & ZE & ZE & NS & NB \\
\hline ZE & PB & PS & ZE & NS & NB \\
\hline PS & PB & PS & ZE & ZE & ZE \\
\hline PB & PB & PS & NS & ZE & ZE \\
\hline
\end{tabular}

\section{IV.SIMULATION RESULTS}

The Electrical characteristics of $20 \mathrm{~W}$ solar panel are shown Table 2.

\section{.TABLE II CHARACTRISTICS OF PANEL}

\begin{tabular}{|l|l|}
\hline Parameters & Values \\
\hline Maximum power & $20 \mathrm{~W}$ \\
\hline Maximum voltage & $17.64 \mathrm{~V}$ \\
\hline Maximum current & $1.18 \mathrm{~A}$ \\
\hline Open circuit voltage & $21.64 \mathrm{~V}$ \\
\hline Short circuit current & $1.23 \mathrm{~A}$ \\
\hline
\end{tabular}

The Simulink block of Type 1 FLC system is shown inFig.9. The power versus voltage and current versus voltage graph is shown in Fig.10 and Fig.11.The comparison of Type 1 Fuzzy logic controller and perturb and observe method is simulated using MATLAB and output voltage and current is measured, and it is shown in Fig.12 and Fig. 13.

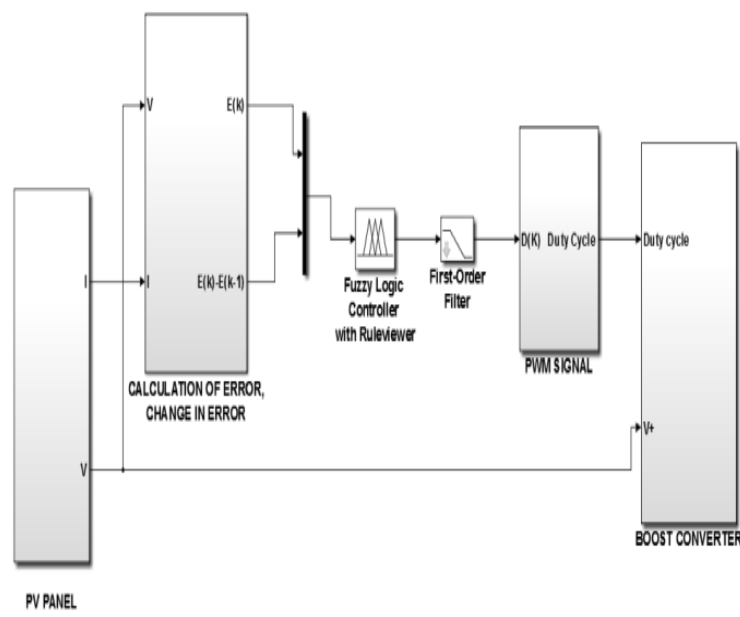

Fig.9.Simulink model of overall system 


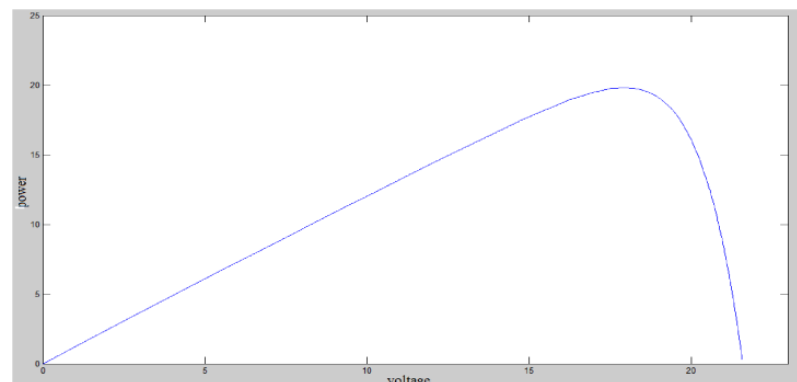

Fig. 10.Power versus voltage curve under STC

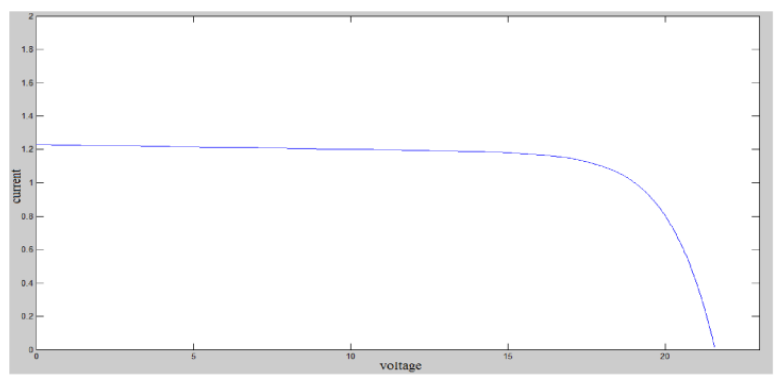

Fig. 11.Current versus voltage curve under STC

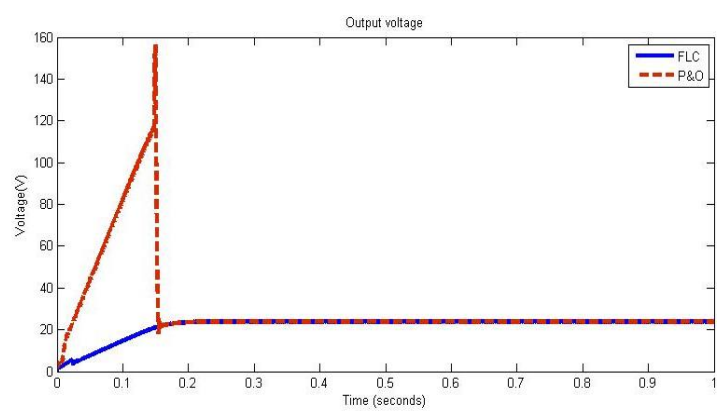

Fig. 12. Output voltage

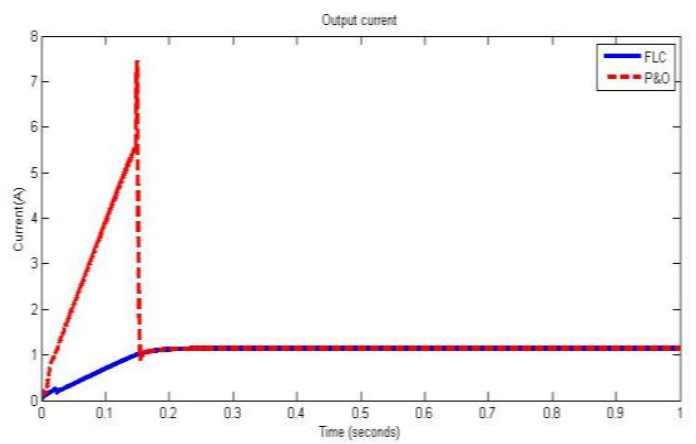

Fig. 13.Output current

\section{CONCLUSION}

The Tracking of Maximum Power Point of photo voltaic systems using fuzzy logic controller is presented here. The performance of this technique has been evaluatedwith Matlab/Simulink. The simulation results show that the FLC technique presentsa good performance and it is an excellent solution regarding the best efficiency.

\section{ACKNOWLEDGMENT}

Authors gratefully acknowledge the support received from NMAM Institute of Technology, Nitte Education Trust and VTU, Belagavi in carrying out the research work.

\section{REFERENCES}

[1] Daniel W.Hart, "Power Electronic"s, Valparaiso University,Valparaiso,Indiana,McGraw-Hill publication,2011

[2] Aparna K P, Priya R, SindhuSuryanarayanan, "Modeling and Simulation of a PV System using DC-DC Converter,"International Journal of Latest Research in Engineering and Technology (IJLRET),Volume 1 Issue 2,July 2015

[3] AkashGarg, R.SaidaNayak, Sushma Gupta,"Comparison of Perturb and Observe method and Fuzzy Logic Controller in MPPT for Photo Voltaic (PV) Applications by Using MATLAB/Simulink,"IOSR Journal of Electrical and Electronics Engineering,Volume 10, Issue 4 Ver. I ,July Aug. 2015

[4] L. Bouselham , M. Hajji and B. Hajji "Hardware Implementation of Fuzzy Logic MPPT Controller on a FPGA Platform ,"ENSAUMP, Morocco,2015 IEEE 2015.

[5] ShilpaSreekumar,Anish Benny, "Fuzzy Logic Controller Based Maximum Power Point Tracking of Photovoltaic System Using Boost Converter," Dept. of Electrical and Electronics Engineering,IEEE - 31661

[6] Mei ShanNgan, CheeWei Tan, "A Study of Maximum Power Point Tracking Algorithms for Stand-alone Photovoltaic Systems,"2011 IEEE.

[7] T. Esram and P. L Chapman, "Comparison of PV array maximum power point tracking techniques,"IEEE Transactions on energy conversion, Vol.22,no.2pp. 439449,2007

[8] PankajKapadeeya1, Prof R.P.Sukhadia2, "Modeling and simulation of photovoltaic system with Boost converter using fuzzy logic controller," ISSN,2016. 